\title{
Maternal Risk Factors Associated with Cleft Lip with or without Cleft Palate: A Review
}

\author{
Factores de Riesgo Materno Asociados con el Labio Fisurado con o sin Paladar Hendido: Una Revisión
}

\author{
Catalina Barrera*, $\&$ Naiara Mezarobba*
}

BARRERA, C. \& MEZAROBBA, N. Maternal risk factors associated with cleft lip with or without cleft palate: A review. Int. J. Odontostomat., 10(2):359-368, 2016.

ABSTRACT: Disruptions in the development of the nasal and oral structures lead to cleft palate and cleft lip. There are many different factors that can affect this development such as genetic, mechanical traumas or teratogeny. The oral clefts are one of the most common birth defects worldwide affecting approximately 1 in 700 to 1000 children. The development of oral clefts is multifactorial and affect a significant portion of the population. The study results showed that smoking is the risk factor most associated with oral clefts (OR 1.09 to 2.11) and the least associated is the ingestion of folic acid (OR 0.59). Many of the risk factors discussed in this article will show an increase in the development of oral clefts although, some of the data could not be effectively compared due to differences in the methodology of each study and the subjective measures used.

KEY WORDS: cleft palate, cleft lip, maternal risk factors.

\section{INTRODUCTION}

The oral, nasal and pharyngeal structures are important not only to speech but also to normal swallowing and development of the face. These structures are the most commonly affected by facial anomalies, including cleft palate and cleft lip. The human palate consists of a bony hard palate and fibromuscular soft palate. The hard palate consists of two fused bones which when not fused properly leave a gap between the two pieces establishing a connection between the oral and nasal cavities (Kummer, 2013). It is further divided into primary and secondary portions. The primary palate lies anterior to the incisive foramen, and the secondary palate lies posterior separating the nasal passage from the pharynx (Burg et al., 2016). The soft palate has an oral and a nasal surface. The oral surface is rich in mucus and fine blood vessels, the nasal surface makes the connection between the nasal cavity and the posterior pharyngeal wall (Kummer). Embryonic development of the palate occurs between the 4th and 12th to 13th weeks of life. During that time, the basic morphology of the face is formed by the fusion of the five basic facial prominences (Burg et al.).

Disruptions at any stage of the palate development can result in cleft palate with or without cleft lip (Yu et al., 2009). Clefting of the primary palate most often occurs between the primary and secondary palates at the incisive foramen that separates the lateral incisors and canine teeth (Burg et al.). Clefting of the secondary palate may arise from failure of the palatal shelves to elevate, adhere or fuse, which may be due to genetic, mechanical or teratogenic factors that perturb the stepwise growth, rotation, and fusion of the prominences (Burg et al.). Clefts affecting the palate are grossly classified as unilateral (incomplete vs. complete), bilateral (incomplete vs. complete), or submucous, it is said to be complete when the gap reaches the nasal cavity involving both the hard and soft palate (Burg et al.).

\footnotetext{
* DDS, Thornill, Canada.

" Medicine, Universidade do Sul de Santa Catarina. University of Toronto, Toronto, Canada.
} 
Oral clefts are one of the most common birth defects. Worldwide, the birth prevalence of cleft palate (CP) and cleft lip (CL) with or without CP (CLP) is approximately 1 in every 700 to 1000 live births (Matthews et al., 2015), being more common in Asians (approximately 1:400) and less common in Africans and African descendants (1:1500) (Yu et al.). The Canadian government reported the rate of orofacial clefts using data collected by the Canadian Congenital Anomalies Surveillance System (CCASS). The mean of national birth prevalence of clef lip or cleft palate (CL/P) and CP in 1989 and 1999 was 1.08 and 0.77 per 1000 births, respectively (Health Canada, 2002).

With our review we intend clarify maternal risk factors that relate to cleft palate, the information is summarized to establish the risk factors that have a stronger relationship to develop clef palate and cleft lip with or without cleft palate, and provide a guide to advise pregnant patients.

\section{MATERIAL AND METHOD}

This review was performed using scientific literature through the National Library of Medicine, Washington, DC (MEDLINE/PubMed) and Google Scholar, the keywords were Cleft palate AND smoking, Cleft palate AND supplements, Cleft palate AND alcohol, Cleft palate AND diabetes mellitus, Cleft palate AND obesity, Cleft palate AND Bereavement, Cleft palate AND corticosteroids, Cleft palate AND environmental, Cleft palate and organic solvents, Cleft palate AND zinc (plasma levels).

\section{RESULTS}

Thirty articles were studied. Each risk factor was described according to categories, country, prevalence and CL/P type. The literature is abundant about maternal risk factors and genes involved. In our study, we identified ten maternal risk factors that developed cleft palate with or without cleft lip. Exposure to cigarette smoke was the risk factor that obtained a higher correlation with CL/P. Every study is different according to the categories of exposure, but some evidences clarified that both active and passive smoking have the same potential to develop cleft palate (Sabbagh et al., 2015).
When it comes to supplements, the studies differ a lot in regard of methods. A relationship between deficiency of folic acid and development of a cleft palate cannot be clearly established. In fact, one of the reviews stated that there is no strong evidence for an association between oral clefts and folic acid intake alone (Johnson \& Little, 2008). In regard to alcohol intake, we came across the same situation. The measurement of the amount of drink is not very precise, and the different types of alcohol can affect the outcome differently. If a drink has a higher alcohol content by volume it has a higher risk to develop cleft palate (Romitti et al., 2008).

However, obesity and diabetes mellitus were proven to have a well established relationship to the development of cleft palate. According to a multicenter case-control study it was established that pregestational diabetes mellitus was associated with a wide range of birth defects (Correa et al., 2008).

When it comes to bereavement or maternal stress, it relates to the mother's concerns and complicated life events. These were all associated to the development of cleft palate. However, it is not strongly established because the evidence varies due to the methods. A population-based cohort study found that a statistically significant increase in the risk of development of oral cleft was primarily due to maternal bereavement and the death of a close relative (Ingstrup et al., 2013). In contrast, the use of corticosteroids showed little evidence in the development of orofacial clefts (Källén, 2003; Hviid \& Molgaard-Nielsen, 2011; Skuladottir et al., 2014).

In environmental risk factors, two articles mentioned the maternal exposure to air pollution and how it affects the development of cleft palate in the chart below. One population-based case-control study provides new evidence that exposure to outdoor air O3 during the first and second month of pregnancy may increase the risk of CL/P (Hwang \& Jaakkola, 2008). On the other hand, another study found that there was little consistent evidence associating cleft malformations with maternal exposure to ambient air pollutants (Marshall et al., 2010). Furthermore, when the mother is exposed to organic solvents she is more likely to give birth to a child with cleft palate. A retrospective study suggests that maternal occupational exposure to chlorinated solvents during early pregnancy is positively associated with the prevalence of neural tube defects (Desrosiers et al., 2012). 
BARRERA, C. \& MEZAROBBA, N. Maternal risk factors associated with cleft lip with or without cleft palate: A review. Int. J. Odontostomat., 10(2):359-368, 2016.

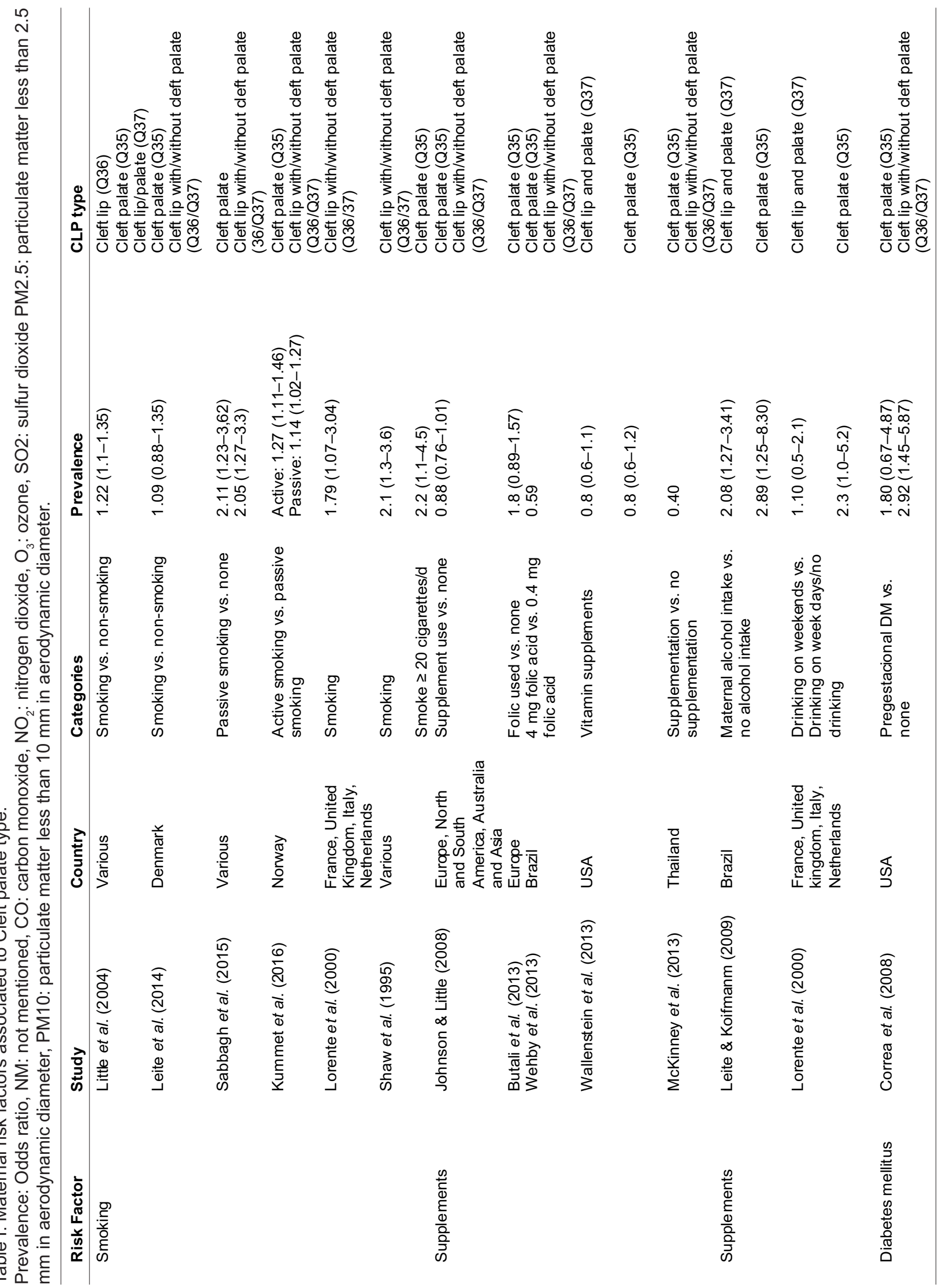


BARRERA, C. \& MEZAROBBA, N. Maternal risk factors associated with cleft lip with or without cleft palate: A review. Int. J. Odontostomat., 10(2):359-368, 2016.
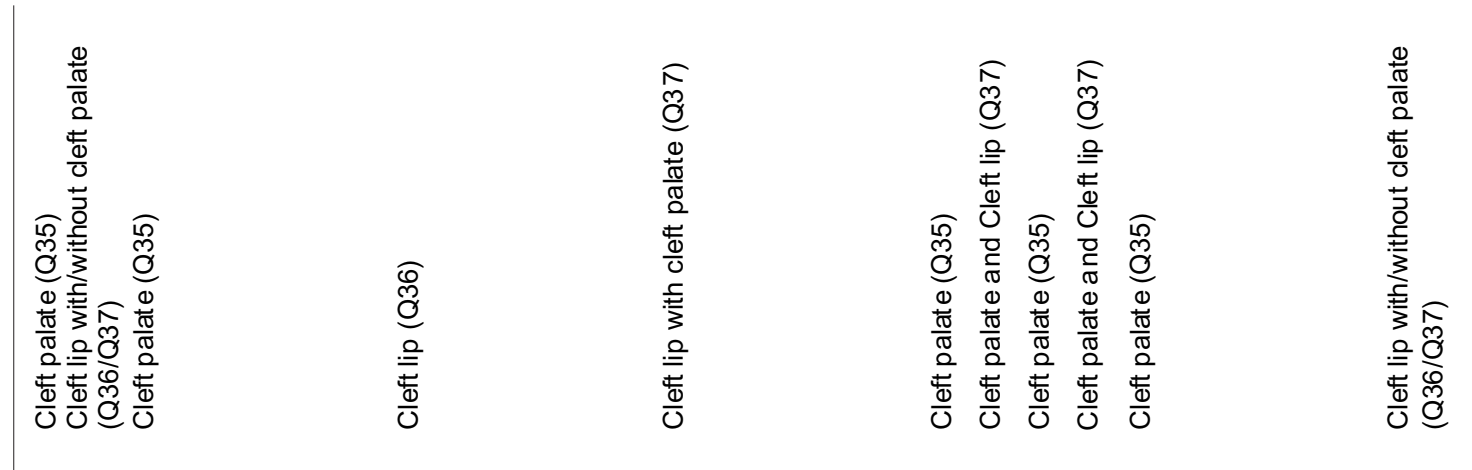

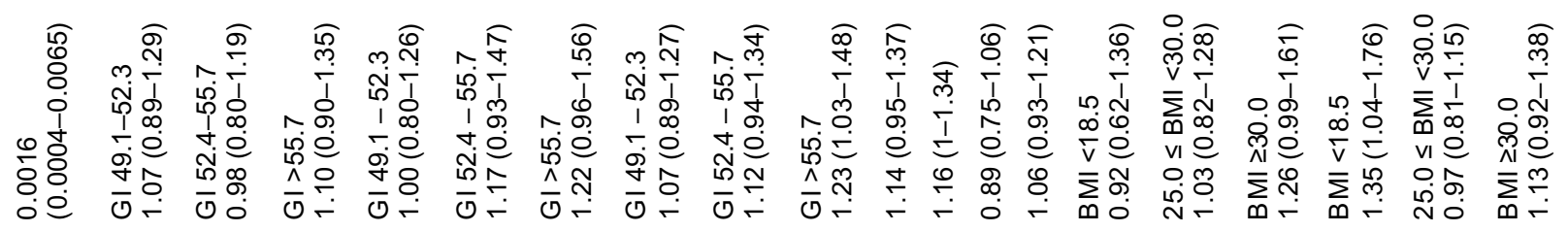
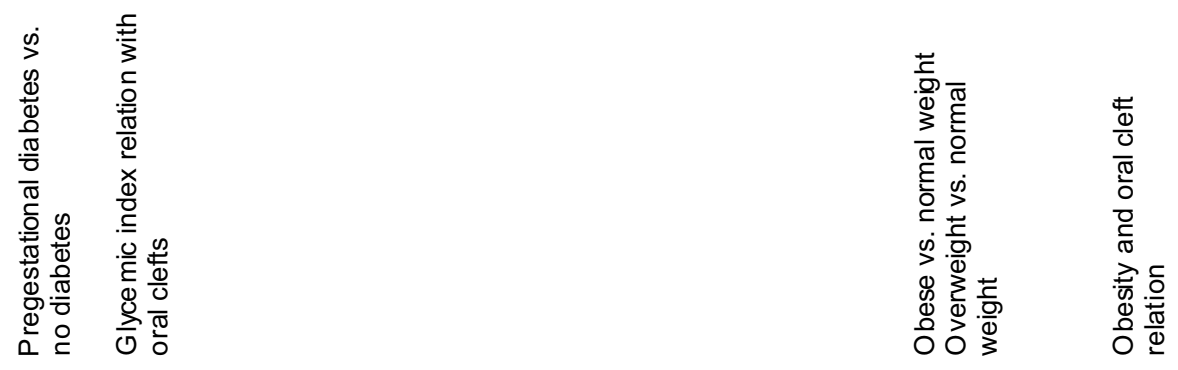

重

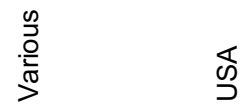

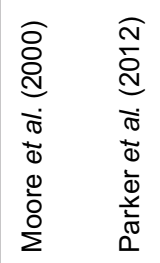

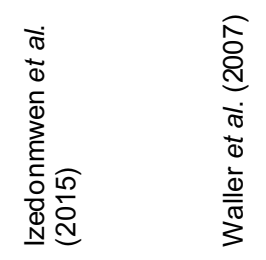

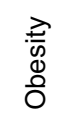


BARRERA, C. \& MEZAROBBA, N. Maternal risk factors associated with cleft lip with or without cleft palate: A review. Int. J. Odontostomat., 10(2):359-368, 2016.

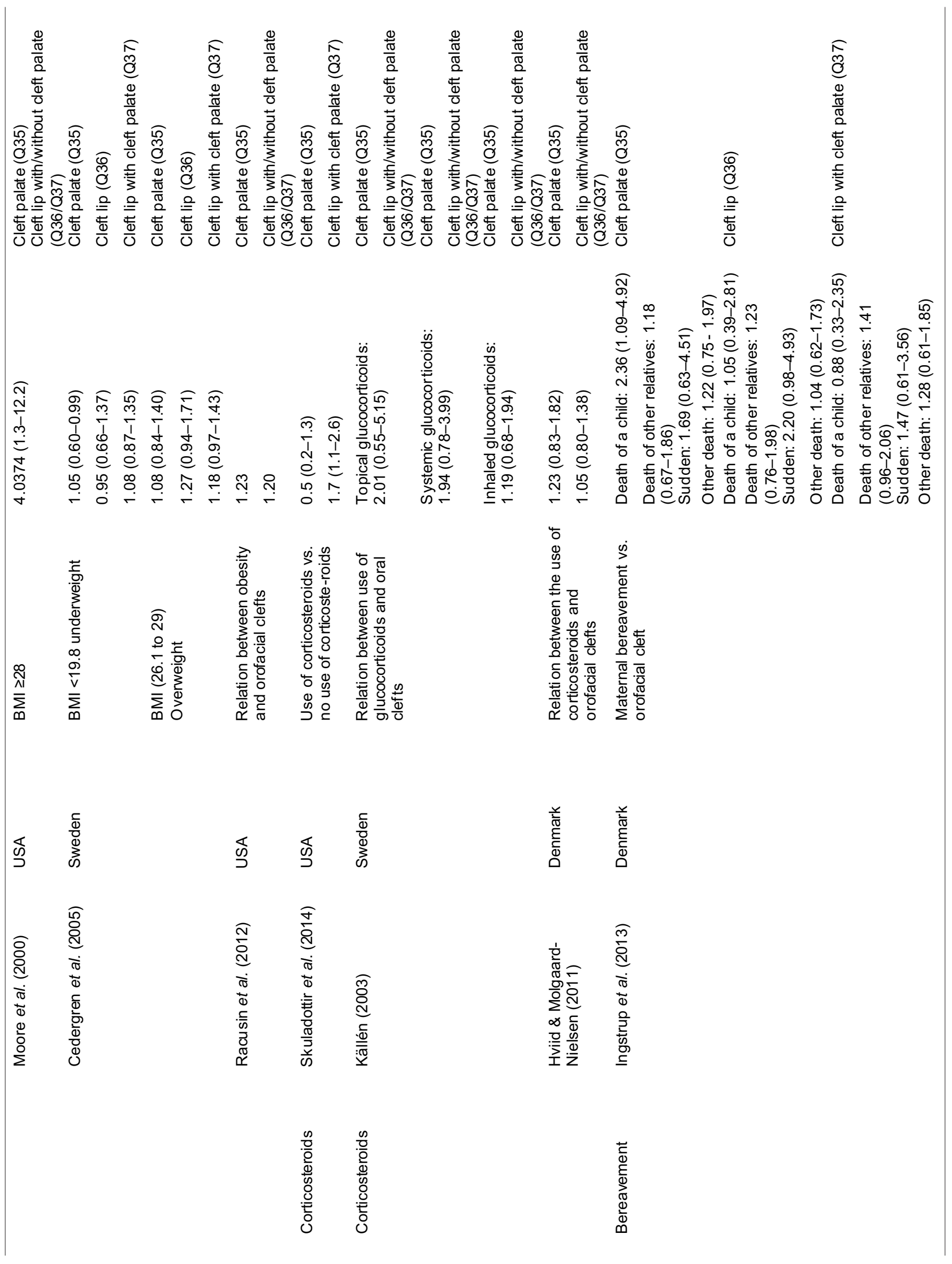




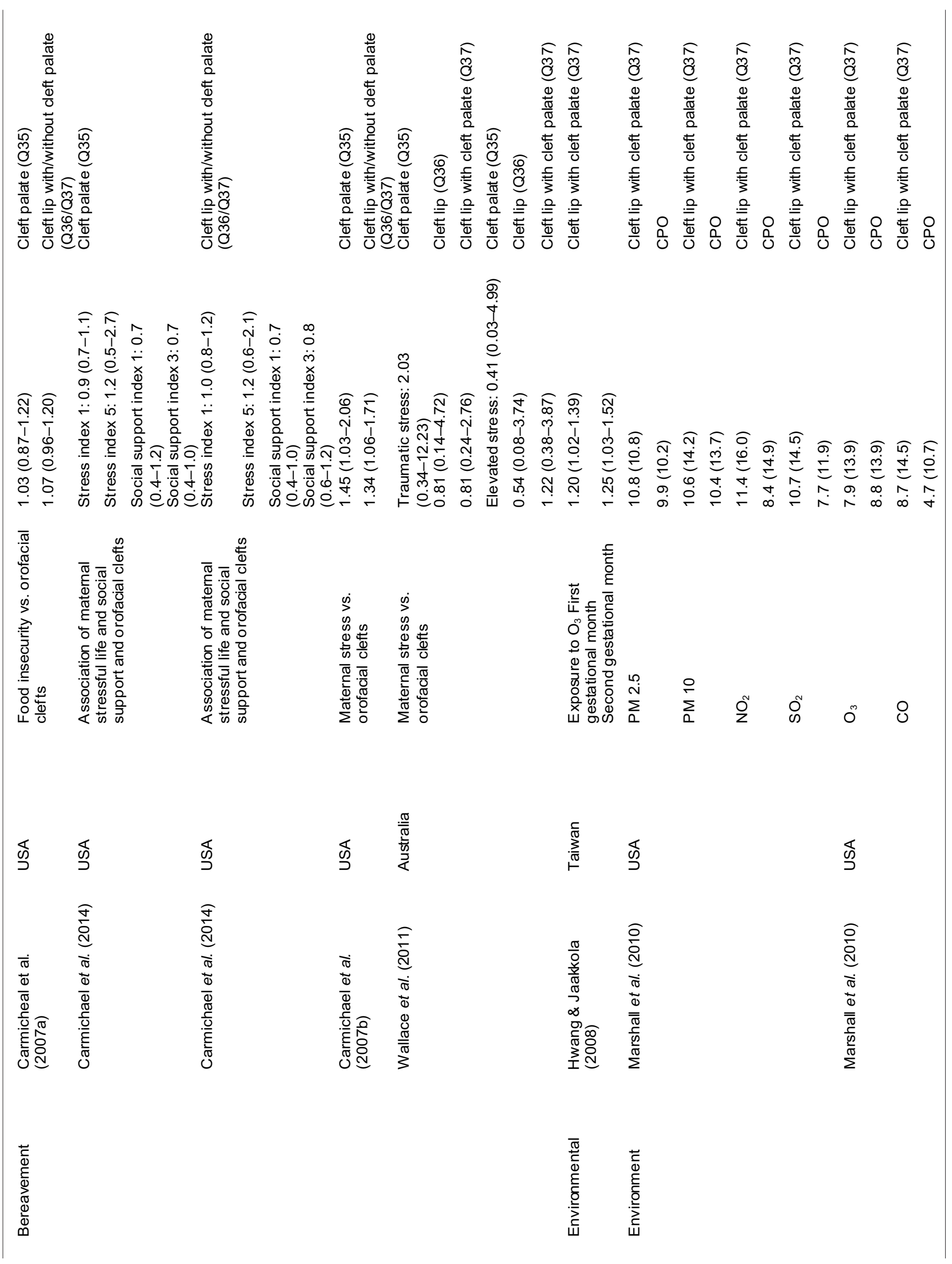


BARRERA, C. \& MEZAROBBA, N. Maternal risk factors associated with cleft lip with or without cleft palate: A review. Int. J. Odontostomat., 10(2):359-368, 2016.

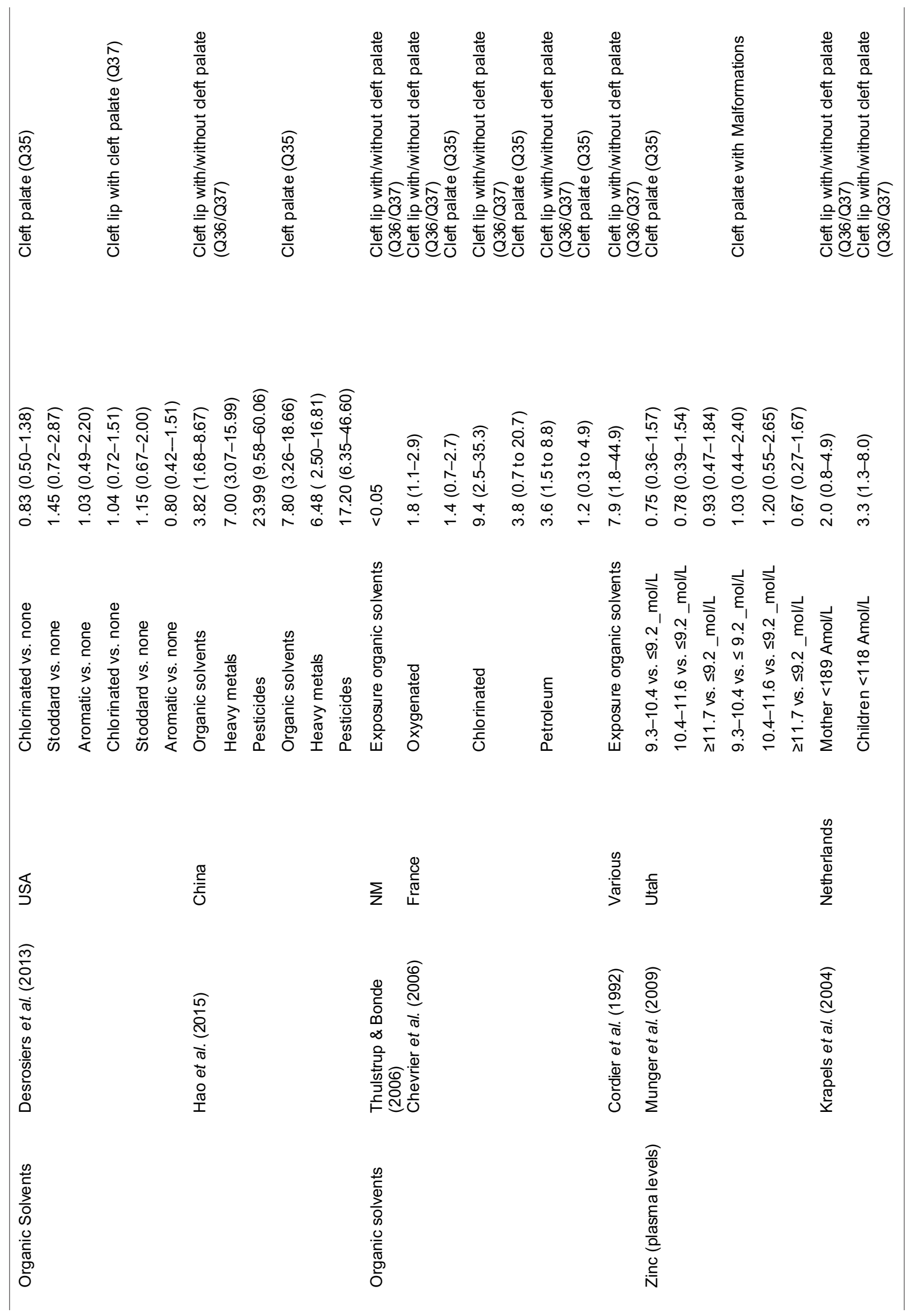


The literature for zinc (plasma levels) deficiency and its relationship with cleft palate is very limited. Were included two articles that demonstrate that low levels of zinc contribute to the development of cleft palate (Krapels et al., 2004; Munger et al., 2009).

\section{DISCUSION}

The present study lends support to the statement that the environment affects the fetus and pre-existent maternal risk factors are potential causes to the development of cleft palate. The most damaging risk factor is the exposure to smoking (active or passive). The majority of literature mentions smoking as a risk factor that causes numerous types of congenital malformations, including CL/P. The proportion of women who smoke in developed countries is currently estimated in $24 \%$, while in developing countries it is around $7 \%$. It is estimated that tobacco consumption is rising at about $3.4 \%$ per year. Globally, numbers say that each year, approximately 12 million women smoke during pregnancy (Little et al., 2004). A positive correlation has been found between alcohol intake and smoking. Alcohol is also a high, independent, risk factor for malformations (Leite et al., 2014). Likewise, alcohol is a known folic acid antagonist and as such has been shown to be associated with an increased risk of clefting (Romitti et al.). However, there is not enough evidence to prove that folate intake will help prevent $\mathrm{CL} / \mathrm{P}$. A systematic review and meta-analysis clarifies that multivitamin use inearly pregnancy may protect against oral clefts, but this association may be confounded by other lifestyle factors (Johnson \& Little).

Obesity is a well known epidemic and it is affecting the entire world. The incidence of obesity in pregnancy has increased over the past two decades concomitant with an increasing prevalence among the general reproductive-age population (Racusin et al., 2012). Several studies suggest that maternal obesity is associated with an increased risk of neural tube defect and facial clefting. In a prospective study, it was established that obesity is a risk factor to the development of congenital defects and it is suggested as well that maternal obesity and diabetes mellitus may act synergistically in the pathogenesis of congenital anomalies (Moore et al., 2000).

Emotional stress during the antenatal period has previously been associated with congenital anomalies. In a large population-based cohort study it was found a significant statistical increase of the risk of oral cleft after maternal bereavement due to the death of a close relative. When mothers lost a relative due to a sudden death, the risk of oral cleft in the offspring was increased (OR: 1.76, 95\% Cl: 1.06; 2.94) (Ingstrup et al.). The evidence shows a positive relationship between stress factors during pregnancy and CL/P. Nevertheless, future studies could improve the methods by which stress factors, levels of maternal cortisol and the period in which life changing events occur are defined.

One of the poorest relationships observed was between the use of corticoids and the development of CL/P. Studies showed that corticoids play only a small role in the origin of orofacial clefts (Källén; Hviid \& Molgaard-Nielsen; Skuladottir et al.). Similarly, it has not been proven that there is a relationship between exposure to organic solvents and the disease. In one of the reviews it was observed that there is no convincing evidence that links occupational exposure to organic solvents during pregnancy and birth defects (Thulstrup \& Bonde, 2006).

Air pollution could influence the development of oral clefts by various biologic mechanisms, including hemodynamic, anoxic events, oxidative stress and toxicity to certain cell populations during pregnancy (Hwang \& Jaakkola). In a population-based case-control study, it was observed that exposure to outdoor air O3 during the first and second trimester of pregnancy may increase the risk of CL/P (Hwang \& Jaakkola). However, a logistic regression study found that the evidence is not enough to establish an association between air pollutants and cleft defects (Marshall et al.).

Zinc is a co-factor for several metalloenzymes and a constituent of proteins, hormones and neuropeptides. It is crucial for embryonic development, cellular multiplication, differentiation and apoptosis, as well as for the integrity of cellular membranes (Krapels et al.). The role of maternal zinc nutrition in human oral clefts is unclear. A study showed that a poor maternal zinc status may become a risk factor only when zinc status is highly compromised, in another study they observed low maternal zinc is associated with the risk for having a child with CL/P (Krapels et al.; Munger et al.).

\section{CONCLUSION}

Through the results, we can conclude that the causes for cleft lip and cleft palate are multivariable. 
The risk factor that had the highest relation with the development of cleft lip and palate was smoking. On the other end of the scale, acid folic intake had the least association with the development of these diseases. There are many risk factors that could not be thoroughly evaluated because of the many different methods and its non-precise measures. Nonetheless, all of the risk factors presented showed an increase in the development of cleft lip and/or cleft palate.

\section{ACKNOWLEDGEMENTS}

We would like to thank Dr. Brian Price, Dr. Hagen Klieb, Mark Ainlay for all their help. Sources of funding for research: PUBMED and Google scholar.

BARRERA, C., MEZAROBBA NAIARA. Factores de riesgo materno asociados con el labio fisurado con o sin paladar hendido: Una revisión. Int. J. Odontostomat., 10(2):359-368, 2016.

RESUMEN: Las interrupciones en el desarrollo de las estructuras nasales y orales conducen al paladar hendido y labio leporino. Hay muchos factores diferentes que pueden afectar este desarrollo, tal como los traumas o teratogenia mecánica genética. Las hendiduras orales son uno de los defectos de nacimiento más comunes en todo el mundo y afectan aproximadamente a 1 de cada 700 a 1000 niños. El desarrollo de fisuras orales es multifactorial y afecta a una parte significativa de la población. Los resultados del estudio mostraron que el tabaquismo es el factor de riesgo que más se asocia con fisuras orales (OR 01,09 a 02,11) y el menos asociado es la ingestión de ácido fólico (OR 0,59). Muchos de los factores de riesgo descritos en este artículo demuestran un aumento en el desarrollo de fisuras orales. No obstante, algunos de los datos no pudieron ser comparados con eficacia debido a las diferencias en la metodología de cada estudio y las medidas subjetivas utilizadas.

PALABRAS CLAVE: paladar hendido, labio leporino, factores de riesgo materno.

\section{REFERENCES}

Burg, M. L.; Chai, Y.; Yao, C. A.; Magee, W. 3rd. \& Figueiredo, J. C. Epidemiology, Etiology, and Treatment of Isolated Cleft Palate. Front. Physiol., 7:67, 2016.

Butali, A.; Little, J.; Chevrier, C.; Cordier S.; Steegers-Theunissen, R.; Jugessur, A.; Oladugba, B. \& Mossey, P. A. Folic acid supplementation use and the MTHFR C677T polymorphism in orofacial clefts etiology: An individual participant data pooledanalysis. Birth Defects Res. A Clin. Mol. Teratol., 97(8):50914, 2013.
Carmichael, S. L.; Yang, W.; Herring, A.; Abrams, B. \& Shaw, G. $M$. Maternal food insecurity is associated with increased risk of certain birth defects. J. Nutr., 137(9):2087-92, 2007 a.

Carmichael, S. L.; Shaw, G. M.; Yang, W.; Abrams, B. \& Lammer, E. J. Maternal stressful life events and risks of birth defects. Epidemiology, 18(3):356-61, 2007b.

Carmichael, S. L.; Ma, C.; Tinker, S.; Rasmussen, S. A.; Shaw, G. M. \& National Birth Defects Prevention Study. Maternal stressors and social support as risks for delivering babies with structural birth defects. Paediatr. Perinat. Epidemiol., 28(4):338-44, 2014.

Cedergren, M. \& Källén, B. Maternal obesity and the risk for orofacial clefts in the offspring. Cleft Palate Craniofac. J., 42(4):367-71, 2005.

Chevrier, C.; Dananché, B.; Bahuau, M.; Nelva, A.; Herman, C.; Francannet, C.; Robert-Gnansia, E. \& Cordier, S. Occupational exposure to organic solvent mixtures during pregnancy and the risk of non-syndromic oral clefts. Occup. Environ. Med., 63(9):617-23, 2006.

Cordier, S.; Ha, M. C.; Ayme, S. \& Goujard, J. Maternal occupational exposure and congenital malformations. Scand. J. Work Environ. Health, 18(1):11-7, 1992.

Correa, A.; Gilboa, S. M.; Besser, L. M.; Botto, L. D.; Moore, C. A.; Hobbs, C. A.; Cleves, M. A.; Riehle-Colarusso, T. J.; Waller, D. K. \& Reece, E. A. Diabetes mellitus and birth defects. Am. J. Obstet. Gynecol., 199(3):237.e1-9, 2008.

Desrosiers, T. A.; Lawson, C. C.; Meyer, R. E.; Richardson, D. B.; Daniels, J. L.; Waters, M. A.; van Wijngaarden, E.; Langlois, P. H.; Romitti, P. A.; Correa, A.; Olshan, A. \& National Birth Defects Prevention Study. Maternal occupational exposure to organic solvents during early pregnancy and risks of neural tube defects and orofacial clefts. Occup. Environ. Med., 69(7):493-9, 2012.

Hao, Y.; Tian, S.; Jiao, X.; Mi, N.; Zhang, B.; Song, T.; An, L.; Zheng, $X$. \& Zhuang, D. Association of parental environmental exposures and supplementation intake with risk of nonsyndromic orofacial clefts: A case-control study in Heilongjiang Province, China. Nutrients, 7(9):7172-84, 2015.

Hviid, A. \& Molgaard-Nielsen, D. Corticosteroid use during pregnancy and risk of orofacial clefts. C. M. A. J., 183(7):796804, 2011.

Hwang, B. F. \& Jaakkola, J. J. Ozone and other air pollutants and the risk of oral clefts. Environ. Health Perspect., 116(10):14115, 2008.

Ingstrup, K. G.; Liang, H.; Olsen, J.; Nohr, E. A.; Bech, B. H.; Wu, C. S. \& Christensen, K. \& Li, J. Maternal bereavement in the antenatal period and oral cleft in the offspring. Hum. Reprod., 28(4):1092-9, 2013.

Izedonmwen, O. M.; Cunningham, C. \& Macfarlene, T. V. What is the risk of having offspring with cleft lip/palate in pre-maternal obese/overweight women when compared to pre-maternal normal weight women? A systematic review and meta-analysis. J. Oral Maxillofac. Res., 6(1):e1, 2015. 
Johnson, C. Y. \& Little, J. Folate intake, markers of folate status and oral clefts: is the evidence converging? Int. J. Epidemiol., 37(5):1041-58, 2008.

Källén, B. Maternal drug use and infant cleft lip/palate with special reference to corticoids. Cleft Palate Craniofac. J., 40(6):6248, 2003.

Krapels, I. P.; Rooji, I. A.; Wevers, R. A.; Zielhuis, G. A.; Spauwen, P. H.; Brussel, W. \& Steegers-Theunissen, R. P. Myo-inositol, glucose and zinc status as risk factors for non-syndromic cleft lip with or without cleft palate in offspring: a case-control study. B. J. O. G., 111(7):661-8, 2004.

Kummer, A. W. Cleft Palate \& Craniofacial Anomalies: Effects on Speech and Resonance. $3^{\text {rd }}$ ed. Delmar, Cengage Learning, 2013.

Leite, I. C. \& Koifman, S. Oral clefts, consanguinity, parental tobacco and alcohol use: a case-control study in Rio de Janeiro, Brazil. Braz. Oral Res., 23(1):31-7, 2009.

Leite, M.; Albieri, V.; Kjaer, S. K. \& Jensen, A. Maternal smoking in pregnancy and risk for congenital malformations: results of a Danish register-based cohort study. Acta Obstet. Gynecol. Scand., 93(8):825-34, 2014.

Little, J.; Cardy, A. \& Munger, R. G. Tobacco smoking and oral clefts: a meta-analysis. Bull. World Health Organ., 82(3):2138, 2004.

Marshall, E. G.; Harris, G. \& Wartenberg, D. Oral cleft defects and maternal exposure to ambient air pollutants in New Jersey. Birth Defects Res. A Clin. Mol. Teratol., 88(4):205-15, 2010.

Matthews, J. L.; Oddone-Paolucci, E. \& Harrop, R. A. The epidemiology of cleft lip and palate in Canada, 1998 to 2007. Cleft Palate Craniofac. J., 52(4):417-24, 2015.

McKinney, C. M.; Chowchuen, B.; Pitiphat, W.; DeRouen, T.; Pisek, A. \& Godfrey, K. Micronutrients and oral clefts: a case-control study. J. Dent. Res., 92(12):1089-94, 2013.

Lorente, C.; Cordier, S.; Goujard, J.; Aymé, S.; Bianchi, F.; Calzolari, E.; De Walle, H. E. \& Knill-Jones, R. Tobacco and alcohol use during pregnancy and risk of oral clefts. Occupational Exposure and Congenital Malformation Working Group. Am. J. Public Health, 90(3):415-9, 2000.

Moore, L. L.; Singer, M. R.; Bradlee, M. L.; Rothman, K. J. \& Milunsky, A. A prospective study of the risk of congenital defects associated with maternal obesity and diabetes mellitus. Epidemiology, 11(6):689-94, 2000.

Munger, R. G.; Tamura, T.; Johnston, K. E.; Feldkamp, M. L.; Pfister, R. \& Carey, J. C. Plasma zinc concentrations of mothers and the risk of oral clefts in their children in Utah. Birth Defects Res. A Clin. Mol. Teratol., 85(2):151-5, 2009.

Parker, S. E.; Werler, M. M.; Shaw, G. M.; Anderka, M.; Yazdy, M. M. \& National Birth Defects Prevention Study. Dietary glycemic index and the risk of birth defects. Am. J. Epidemiol., 176(12):1110-20, 2012.
Racusin, D.; Stevens, B.; Campbell, G. \& Aagaard, K. M. Obesity and the risk and detection of fetal malformations. Semin. Perinatol., 36(3):213-21, 2012.

Romitti, P. A.; Sun, L.; Honein, M. A.; Reefhuis, J.; Correa, A. \& Rasmussen, S. A. Maternal periconceptional alcohol consumption and risk of orofacial clefts. Am. J. Epidemiol., 166(7):775-85, 2007.

Sabbagh, H. J.; Hassan, M. H.; Innes, N. P.; Elkodary, H. M.; Little, J. \& Mossey, P. A. Passive smoking in the etiology of nonsyndromic orofacial clefts: a systematic review and metaanalysis. PLoS One, 10(3):e0116963 2015.

Skuladottir, H.; Wilcox, A. J. Ma, C., Lammer, E. J., Rasmussen, S. A.; Werler, M. M.; Shaw, G. M. \& Carmichael, S. L. Corticosteroid use and risk of orofacial clefts. Birth Defects Res. A Clin. Mol. Teratol., 100(6):499-506, 2014.

Shaw, G. M.; Wasserman, C. R.; Lammer, E. J.; O'Malley, C. D.; Murray, J. C.; Basart, A. M. \& Tolarova, M. M. Orofacial clefts, parental cigarette smoking, and transforming growth factoralpha gene variants. Am. J. Hum. Genet., 58(3):551-61, 1996.

Thulstrup, A. M. \& Bonde, J. P. Maternal occupational exposure and risk of specific birth defects. Occup. Med. (Lond.), 56(8):532-43, 2006.

Wehby, G. L.; Félix, T. M.; Goco, N.; Richieri-Costa, A.; Chakraborty, H.; Souza, J.; Pereira, R.; Padovani, C.; Moretti-Ferreira, D. \& Murray, J. C. High dosage folic acid supplementation, oral cleft recurrence and fetal growth. Int. J. Environ. Res. Public Health, 10(2):590-605, 2013.

Wallace, G. H.; Arellano, J. M. \& Gruner, T. M. Non-syndromic cleft lip and palate: could stress be a causal factor? Women Birth, 24(1):40-6, 2011.

Waller, D. K.; Shaw, G. M.; Rasmussen, S. A.; Hobbs, C. A.; Canfield, M. A.; Siega-Riz, A. M.; Gallaway, M. S.; Correa, A. \& National Birth Defects Prevention Study. Prepregnancy obesity as a risk factor for structural birth defects. Arch. Pediatr. Adolesc. Med., 161(8):745-50, 2007.

Wallenstein, M, B.; Shaw, G, M.; Yang, W. \& Carmichael, S, L. Periconceptional nutrient intakes and risks of orofacial clefts in California. Pediatr. Res., 74(4):457-65, 2013.

Yu, W.; Serrano, M.; Miguel, S. S.; Ruest, L. B. \& Svoboda, K. K. Cleft lip and palate genetics and application in early embryological development. Indian J. Plast. Surg., 42 Suppl.:S35-50, 2009.

Correspondence to:

Dra. Catalina Andrea Barrera Vega

7811 Yonge Street, Apt 708

Thornill, Ontario

CANADA

Received: 03-06-2016

Accepted: 11-08-2016

Emai: catabarrera87ster@gmail.com 